\title{
The predictive factors for length of stay for stroke patients in Taiwan using the path model
}

\author{
Lylnn Chung ${ }^{\mathrm{a}}$, Yen-Ho Wang ${ }^{\mathrm{b}}$, Tsyr-Jang $\mathrm{Chen}^{\mathrm{c}}$ and Ay-Woan Pan ${ }^{\mathrm{d}, \mathrm{e}}$
}

The aim of this study was to examine the predictive factors, and their relative strengths, for predicting length of rehabilitation stay using the path model. One hundred and seventeen stroke patients were recruited from two rehabilitation units in university-affiliated hospitals in northern Taiwan. The Taiwanese Rehabilitation Database System was used to collect the patient's relevant information. Path analysis was used to explore the relative strengths of each predictive factor. The results showed that the ability to engage in self-care activities was the only direct predictor, whereas subjective well-being and cognitive social skills had an indirect effect on the length of rehabilitation stay, mediating through cognitive-social skills and ability to engage in activities of daily living, respectively. The effect of subjective well-being, mediating through cognitive-social skills, on the length of stay was about 1.5 times that of the effects of ability to engage in self-care activities on length of stay. The results of the study confirmed that the ability of stroke patients to engage in self-care activities consistently had a major impact on the length of stay. The effect of subjective well-being of the patients on the rehabilitation outcome raised the issue of psychosocial rehabilitation as an important part of successful rehabilitation services.

Mit dieser Studie sollten die Prädiktivfaktoren und ihre jeweiligen Stärken bei der Prognose der Dauer des Reha-Aufenthalts anhand des Wegmodells untersucht werden. Insgesamt 117 Schlaganfallpatienten wurden aus zwei Reha-Zentren an Universitätskliniken in Nord-Taiwan rekrutiert. Mit Hilfe des taiwanesischen Reha-Datenbanksystems wurden einschlägige Informationen der Patienten zusammengetragen. Anhand der Analyse des kritischen Wegs wurden die relativen Stärken jedes Prädiktivwerts untersucht. Die Ergebnisse zeigten, dass die Fähigkeit, sich mit der Selbstpflege zu befassen, der einzige direkte Prädiktor war, während das subjektiv empfundene Wohl und die kognitiven gesellschaftlichen Fertigkeiten eine indirekte Wirkung auf die Dauer des Reha-Aufenthalts ausübten, vermittelt durch kognitiv-soziale Fertigkeiten und die Fähigkeit, sich an Aktivitäten des täglichen Lebens zu beteiligen. Die Wirkung des subjektiv empfundenen Wohls, vermittelt durch kognitiv-soziale Fertigkeiten, auf die Dauer des Aufenthalts war etwa 1,5mal größer als die Wirkungen der Fähigkeit der Selbstpflege auf die Dauer des Aufenthalts. Die Ergebnisse der Studie belegten, dass die Fähigkeit von Schlaganfallpatienten, sich konstant mit der Selbstpflege zu befassen, eine große Wirkung auf die Aufenthaltsdauer hat. Die Wirkung des subjektiv empfundenen Wohls der Patienten auf das Reha-Ergebnis brachte das Thema der psychosozialen Rehabilitation als einen wichtigen Teil erfolgreicher Reha-Leistungen zur Sprache.

El objetivo de este estudio fue determinar, mediante el uso de un modelo de trayectoria, los factores pronósticos y la utilidad relativa de éstos para predecir la duración del internamiento para llevar a cabo un tratamiento de rehabilitación. Se reclutaron 117 pacientes que habian sufrido un accidente cerebrovascular y que se encontraban internados en dos de las unidades de rehabilitación de hospitales universitarios del norte de Taiwán. Se utilizó el Sistema de Bases de Datos de Taiwán sobre la Rehabilitación para recolectar la información necesaria acerca de los pacientes. Se empleó un análisis de trayectoria para explorar la utilidad relativa de cada factor pronóstico. Los resultados mostraron que la capacidad de participar en actividades de cuidado personal fue el único factor pronóstico directo en estos casos, mientras que el bienestar percibido y las habilidades sociales y cognitivas tuvieron un efecto indirecto sobre la duración del internamiento para la rehabilitación, mediando las habilidades sociales y cognitivas, y la posibilidad de participar en actividades cotidianas, respectivamente. El efecto del bienestar percibido, mediando las habilidades sociales y cognitivas, sobre la duración del internamiento fue 1,5 veces mayor que los efectos de la capacidad para participar en actividades de cuidado personal. Los resultados del estudio confirmaron que la capacidad de los pacientes víctimas de accidentes cerebrovascular para participar en actividades de cuidado personal de manera consistente tuvo un gran impacto en la duración del internamiento. El efecto del bienestar percibido de los pacientes acerca de los resultados de la rehabilitación hizo resaltar el problema de la rehabilitación psicosocial como parte importante de todo servicio de rehabilitación exitoso.

Cette étude avait pour objectif d'examiner les facteurs prédictifs, ainsi que leurs forces relatives, en vue de déterminer la durée des séjours de rééducation selon un modèle de parcours. Cent dix-sept patients victimes d'accidents vasculaires cérébraux ont été recrutés dans deux unités de rééducation d'hôpitaux universitaires au nord de Taïwan. Le système de banque de données de rééducation taïwanais a été utilisé pour collecter les informations relatives aux patients. L'analyse du parcours a été employée pour explorer l'influence relative de chaque facteur prédictif. Le résultat montre que la capacité à 
prendre part à des activités de soins personnels était le seul facteur prédictif direct, tandis que le bien-être subjectif et les compétences sociales cognitives avaient un effet indirect respectivement sur la durée du séjour de rééducation, l'interaction par le truchement des compétences sociales cognitives et la capacité à participer aux activités de la vie quotidienne. L'effet du bien-être subjectif, de l'interaction par le truchement des compétences sociales cognitives et de la durée du séjour était environ une fois et demie plus important que les effets de la capacité à participer à des activités de soins personnels sur la durée du séjour. Les résultats de l'étude confirment que la capacité des victimes d'accidents vasculaires cérébraux à participer à des activités de soins personnels de manière continue a un impact majeur sur la durée du séjour. L'effet du bien-être subjectif du patient sur le résultat de la rééducation soulève la question de l'importance de la rééducation psychosociale pour une mise en œuvre réussie des services de rééducation. International Journal of Rehabilitation Research 29:137-143 @ 2006 Lippincott Williams \& Wilkins.
International Journal of Rehabilitation Research 2006, 29:137-143

Keywords: length of stay, predictive factors, psychosocial rehabilitation, stroke patients

aDepartment of Statistics, College of Business, National Taipei University, Taiwan, bepartment of Physical Medicine and Rehabilitation, College of Medicine, National Taiwan University, Taiwan, 'Department of Mechanical Engineering, Lunghwa University of Science and Technology, Tao-Yuan, Taiwan, ${ }^{\mathrm{d}}$ School of Occupational Therapy, College of Medicine and 'Department of Psychiatry, National Taiwan University, Taiwan.

Correspondence and requests for reprints to A.W. Room 407, 4F, No.17, She-chou Road, School of Occupational Therapy, College of Medicine, National Taiwan University, Taipei, Taiwan. Tel: +886 2 23887415; fax: +886 223710614 ; e-mail: aywoan@ha.mc.ntu.edu.tw

This study was supported and sponsored by the Department of Health of the Republic of China and National Health Research Institute. Grant nos DOH86HR-634, DOH87-HR-634 and DOH88-HR-634.

\section{Received 24 October 2005 Accepted 22 December 2005}

\section{Introduction}

Stroke is one of the leading causes of death in many countries (American Heart Association, 2005; The Stroke Association, 2005). Stroke survivors may be left with physical and cognitive deficits, and often benefit from inpatient rehabilitation. The ability of professionals to predict the outcome of treatment would improve the effectiveness and efficiency of rehabilitation resource use. Many studies have been carried out to identify variables that can predict the outcome of rehabilitation. In the past decade, several studies investigating predictive factors relevant to rehabilitation outcome have revealed that age, gender, severity of illness, activities of daily living (ADL), cognitive functions and psychological well-being are related to the length of inpatient rehabilitation (Stineman and Williams, 1990; Giaquinto et al., 1999; Lin et al., 2003; Counsell et al., 2004). The result of the causal model study of patients with spinal cord injury in Taiwan also showed that ADL directly affects the length of stay of the patients (Chung et al., 2003). To investigate these differing aspects, this study aimed to examine predictive factors and their relative effects on the length of rehabilitation stay, using the path model. The results could provide data on the magnitude and relative importance of each predictor on the outcome variable, and potentially assist clinicians in constructing programs for better rehabilitation services in Taiwan.

The study utilized data from the Taiwanese Rehabilitation Database System (TaRDS) (Pan et al., 2000, 2001a). The TaRDS was established to facilitate inter-institutional comparison of intervention efficacy, to conduct further research on outcome and to provide the baseline data for health care reimbursement. It provides a consistent database for use in program evaluation and quality assurance. The TaRDS consists of three main parts: the patient's demographic data, their scores on the Taiwanese Rehabilitation Functional Scale (TaRFS) and related outcome information (Pan et al., 2000, 2001a). It encompasses three domains: ADL, cognitive-social skills (CSS) and subjective well-being (SWB) (Pan et al., 2001b). The development of these abilities in the patient will allow them to live independently and satisfactorily (Pan et al., 2001a). The TaRDs has evidence of test-retest and inter-rater reliability as well as construct validity (Pan et al., 2001a, 2001b).

The four key predictors for rehabilitation service use were selected because they have been extensively used in previous studies, and have theoretical and empirical relevance to the area in question (Pan, 1994). The predictors include personal characteristics variables, ADL, CSS and SWB. Since patients are usually discharged when their functions recover, length of stay (LOS) in hospital can be used as a proxy for rehabilitation outcome (Rondinelli et al., 1991; Harada et al., 1993; Heinemann et al., 1994).

Age was considered as a predicting variable in the model, as a high association between age and disability has been found in major national surveys (LaPlante, 1991). The functional statuses of patients (ADL, CSS and SWB) were used as predictors for rehabilitation resource use (Stineman and Williams, 1990; Giaquinto et al., 1999; Lin et al., 2003; Counsell et al., 2004). ADL was found to be a dominant factor in previous prediction studies (McGinnis 
Fig. 1

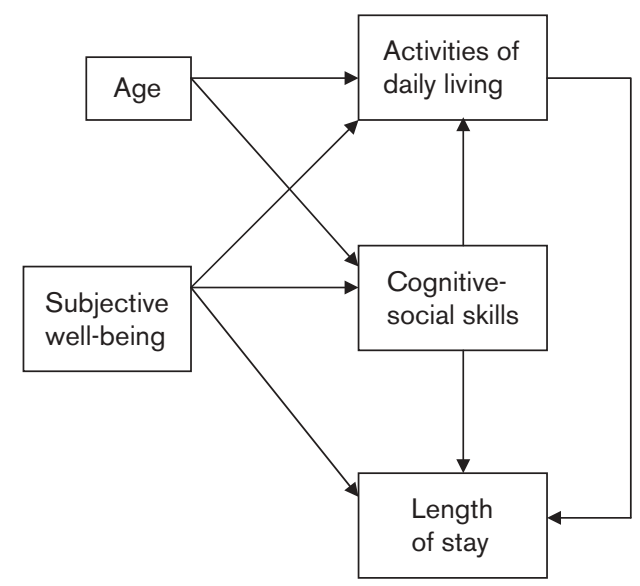

Initial path model.

et al., 1987; Stineman and Williams, 1990; Rondinelli et al., 1991), and we hypothesized that it would directly and negatively affect LOS. Figure 1 shows the relationships between these variables and the directions of the correlations. The assumptions for the hypothesized model were as follows:

(1) The patient's ADL would directly affect LOS negatively, i.e. the LOS would increase as the severity of ADL limitation increases.

(2) As the SWB improves, ADL and CSS would improve, resulting in a decrease in LOS.

(3) As the CSS improves, ADL would improve; therefore, LOS would decrease.

(4) As age increases, CSS and ADL would deteriorate.

\section{Methods}

Patients

Table 1 presents the characteristics of stroke patients in this study. One hundred and seventeen stroke patients (68 men and 49 women), with a mean age of 61 years, were recruited from two rehabilitation units in universityaffiliated hospitals in northern Taiwan. These hospitals are rated as first-class medical centers in Taiwan and serve a variety of patients regardless of diagnosis, severity or complications. To be eligible for this study, a patient needed to meet the following criteria: (1) diagnosed as having had a cerebral vascular accident regardless of lesion site and severity, (2) admitted to the rehabilitation ward for rehabilitation services and (3) willing to participate in the study.

\section{Procedures}

In order to document the outcome of rehabilitation intervention, a reliable functional status measure was
Table 1 Characteristics of stroke patients in the study $(n=117)$

\begin{tabular}{lcl}
\hline & $n(\%)$ & Mean (SD) \\
\hline Gender & $68(58)$ & \\
Male & $49(42)$ & \\
Female & & \\
Diagnosis & $46(39)$ & \\
Left body involvement & $58(50)$ & \\
Right body involvement & $7(6)$ & \\
Bilateral involvement & $6(5)$ & \\
Other stroke & & \\
Education & $69(59)$ & \\
Primary or below & $17(15)$ & $61.1(14.6)$ \\
Middle school & $19(16)$ & $52.7(106.6)$ \\
High school & $11(9)$ & $41.6(21.7)$ \\
College or above & & $26.8(14.9)$ \\
Age (years) & & $14.7(7.9)$ \\
Onset duration (days) & & $25.6(11.0)$ \\
Length of stay (days) & & \\
Activities of daily living & & \\
Subjective well-being & & \\
Cognitive-social skills & &
\end{tabular}

needed (Ottenbacher et al., 1994). Since variation in raters' judgement would contaminate the data (Streiner and Norman, 1989), a proper rater training protocol was necessary. The training protocol of the adopted TaRFS consisted of two sessions of lectures and discussion, with each session lasting approximately $3 \mathrm{~h}$. The content of the course was: (1) an introduction to the background and rating principles of the TaRFS, (2) an introduction to the item definition and an instruction in administration of the TaRFS and (3) pilot testing and feedback.

A trained research assistant invited qualified patients to participate in the study individually. The research plan was approved by the National Taiwan University Hospital ethical committee. An explanation letter and informed consent form was given to the potential participants. After their consent was secured, the patients were recruited for the study. Patients were tested on the TaRFS through performance and scored by trained assistants via observation. The patients were also interviewed for other relevant information within the first week of admission to the rehabilitation ward.

\section{Measures}

The TaRFS was developed based on the consensus that functional status is an important predictor of outcome for inpatient rehabilitation (Harada et al., 1993; Heinemann et al., 1994; Chung et al., 2003). Since the functional status measure encompasses multiple domains (Formations in Health Care, 1992; Uniform Data System for Medical Rehabilitation, 1995; Clark et al., 1997), a multidimensional assessment is needed to obtain a comprehensive view of the patient (Crewe and Dijkers, 1994). Several related scales used worldwide were reviewed (Katz et al., 1963; Mahoney and Barthel, 1965; Bowling, 1997). Of these, the Functional Independence Measure (FIM) (Uniform Data System for Medical Rehabilitation, 1995), Level of Rehabilitation Scale (Formations in Health Care, 1992), Beck Depression 
Scale (Beck et al., 1996), Medical Outcome Study and Short-Form-36 (Ware, 1993) were influential in the construction of the TaRFS. For the SWB subscale, since there were few functional instruments addressing this issue, items related to mood, health perception and perceived competency were included (Ware, 1993; Van den Bos and Triemstra, 1999). In addition to the sampling of related items from these scales, specific cultural background and tool use was addressed in the assessment. For example, for the ADL item 'feeding', the use of chopsticks was one of the abilities performed during evaluation, while, for the item 'bathing', taking a bath on a bench or chair was regarded as acceptable criteria. Furthermore, the item 'illness's influence on social interaction' was included in the SWB subscale, since the Chinese perceive 'saving face' as an important inherent value (Research Team for WHOQOL-Chinese Version, 1999) and becoming ill is seen as 'losing face' by some families. Consequently, many patients will choose not to disclose their illness and disability to their relatives and friends, and this may have a huge impact on the patient's social interactions.

The TaRFS consisted of 20 items covering three domains: ADL, CSS and SWB. Each item was rated on a seven-point rating scale. For the ADL and CSS, the scale ranged from totally dependent (score of 1 ) to totally independent (score of 7); these two scales were rated by occupational therapists. For the SWB, the scale ranged from 'totally disagree with the statement' (score of 1) to 'totally agree with the statement' (score of 7); this scale was rated by the patients themselves. The TaRFS scores represented the amount of assistance needed for the patient to perform specific activity, and the perception of his/her own health and psychological state. Moreover, the TaRFS was designed to rate a patient's performance by actual observation of the patient's performance within the hospital ward environment (Pan et al., 2001a, 2001b; Chung et al., 2003). The manual provided administration instructions and rating definitions. Table 2 lists the individual item of the TaRFS.

Table 2 Taiwanese rehabilitation functional scale

\begin{tabular}{|c|c|c|}
\hline $\begin{array}{l}\text { Activities of daily } \\
\text { living subscale }\end{array}$ & Cognitive-social subscale & $\begin{array}{l}\text { Subjective well-being } \\
\text { subscale }\end{array}$ \\
\hline $\begin{array}{l}\text { (1) Feeding } \\
\text { (2) Grooming }\end{array}$ & $\begin{array}{l}\text { (1) Orientation } \\
\text { (2) Problem solving } \\
\text { - specific }\end{array}$ & $\begin{array}{l}\text { (1) Health perception } \\
\text { (2) Mood }\end{array}$ \\
\hline $\begin{array}{l}\text { (3) Dressing - upper } \\
\text { body } \\
\text { (4) Dressing - lower } \\
\text { body }\end{array}$ & $\begin{array}{l}\text { (3) Problem solving } \\
\text { - general } \\
\text { (4) Comprehension }\end{array}$ & $\begin{array}{l}\text { (3) Influence on social } \\
\text { interaction } \\
\text { (4) Recovery expectation }\end{array}$ \\
\hline $\begin{array}{l}\text { (5) Transfer - chairs } \\
\text { (6) Transfer - toilet } \\
\text { (7) Toileting } \\
\text { (8) Bathing } \\
\text { (9) Mobility } \\
\text { (10) Stairs }\end{array}$ & (5) Expression & (5) Perceived competency \\
\hline
\end{tabular}

\section{Statistical analyses}

Statistical analyses included the descriptive statistics for each variable in the causal model, the computation of correlation coefficients among all variables and the application of path analysis to validate the causal model. The variables used in this study were age, SWB, CSS, $\mathrm{ADL}$ and LOS. LOS was defined as the time from admission to discharge during the rehabilitation stage. The values for the SWB, CSS and ADL were the sum of the item scores in the respective subscales. Path analysis was the generalization of multiple regressions. The $P$-value was set at 0.05 for the overall $F$-statistics and individual $t$-statistics obtained at each step and in each path.

Path analysis was introduced by Sewell Wright and popularized by Duncan (Wright, 1960; Duncan, 1996). The merits of this method were that it allowed interpretation of linear relationships among a set of variables, and the decomposition of correlation into causal effects (direct or indirect effects on LOS) and non-causal effects (due to correlated causes or common causes) (Pedhazur, 1982). The results of path analysis allowed us to know the exact effect of predictive variables on LOS and the relative importance of each predictor in the causal model, through the use of standardized path coefficients. The best-fit model can be obtained by modifying the original model on the basis of the $t$-values, the $P$-value for the $\chi^{2}$-test, and the goodness-of-fit index (GFI) and adjusted GFI (AGFI) (Subhash, 1995). All analyses were performed using Statistical Analysis System 6.12 (SAS Institute, 1990) and LISREL 8.3 (LISREL 8, 1996).

\section{Results}

The average age of the patients was $61.1 \pm 14.6$ years and it was similar to other epidemiological studies in Taiwan medical centers (Yip et al., 1997; Jeng et al., 1998). Sixtyeight (68\%) patients were male. The average LOS was 41.6 days ( $\mathrm{SD}=21.7$ days), the mean scores of $\mathrm{ADL}$ was 26.8 (14.9), the mean CSS score was 25.6 (11) and the mean SWB score was 14.7 (7.9) (Table 1). Table 3 displays regression coefficients and standardized coefficients for the initial causal model as shown in Fig. 1. Four paths were not statistically significant and were therefore deleted from the initial model. These were: age to ADL, age to CSS, CSS to LOS and SWB to LOS. The path CSS to LOS was not significant, and this finding was also reported in studies using FIM (Heinemann et al., 1994) and LORDS-III (Pan, 1994). The path SWB to ADL was not significant at the 0.05 level, but the $P$-value of 0.11 was close to marginal significance at the 0.10 level. We kept this path because an effect of SWB on ADL had been reported (McHugh and Robinson, 1983; Santus et al., 1990; Counsell et al., 2004). This path might have been significant if the sample size had been larger. The revised path model is shown in Fig. 2. 
Table 3 Path analysis for the initial and final models

\begin{tabular}{|c|c|c|c|c|c|}
\hline Dependent variable & Independent variable & Standardized coefficient & Regression coefficient & $P$-value & $R^{2}$ \\
\hline \multicolumn{6}{|l|}{ Initial model } \\
\hline \multirow[t]{2}{*}{ Cognitive-social skills } & Age & -0.1101 & -0.0834 & 0.1544 & 0.3525 \\
\hline & Subjective well-being & $0.5627^{*}$ & $0.7836^{*}$ & $<0.0001^{*}$ & \\
\hline \multirow[t]{3}{*}{ Activities of daily living } & Age & 0.0110 & 0.0112 & 0.8900 & 0.3312 \\
\hline & Cognitive-social skills & $0.4753^{*}$ & $0.6400^{*}$ & $<0.0001^{*}$ & \\
\hline & Subjective well-being & 0.1527 & 0.2864 & 0.1110 & \\
\hline \multirow[t]{3}{*}{ Length of stay } & Activities of daily living & $-0.4094^{*}$ & $-0.5979^{*}$ & $0.0002^{*}$ & 0.1257 \\
\hline & Cognitive-Social skills & 0.1183 & 0.2326 & 0.3252 & \\
\hline & Subjective well-being & 0.0069 & 0.0189 & 0.9499 & \\
\hline \multicolumn{6}{|l|}{ Final model } \\
\hline Cognitive-social skills & Subjective well-being & $0.5838^{*}$ & $0.8130^{*}$ & $<0.0001^{*}$ & 0.3409 \\
\hline \multirow[t]{2}{*}{ Activities of daily living } & Subjective well-being & 0.1517 & 0.2844 & 0.1107 & 0.3311 \\
\hline & Cognitive-social skills & $0.4735^{*}$ & $0.6376^{*}$ & $<0.0001^{*}$ & \\
\hline Length of stay & Activities of daily living & $-0.3380^{*}$ & $-0.4965^{*}$ & $0.0002^{*}$ & 0.1142 \\
\hline
\end{tabular}

Fig. 2

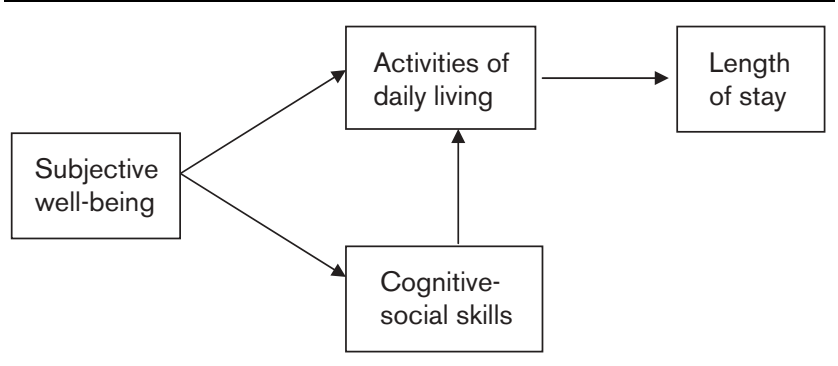

Final path model.

Figure 2 presents the final causal model. Table 3 also reports the result of path analysis for the final model. ADL was the only direct predictor which affected LOS. SWB and CSS affected ADL directly. Both SWB and CSS affected LOS indirectly through ADL. A good fit model should have a GFI $>0.9$ and an AGFI $>0.9$. Failure to reject the null hypothesis leads to the conclusion that the final model fits the data. The results showed GFI $=0.99$ $(>0.9), \quad$ AGFI $=0.97 \quad(>0.9), \quad$ and $P$-value $=0.52$ $(>0.05)$. It suggests that the final causal model fits the data well.

Table 4 shows the decomposition of the total effects into direct, indirect, causal and non-causal components of the final path model. SWB and CSS had strong positive direct effects on CSS and ADL, respectively. In addition, SWB had both direct and indirect effects on ADL; the indirect effect is twice the magnitude of the direct effect on ADL. ADL was the only direct predictor of LOS and had a moderate negative effect on LOS. This indicates that SWB has a remote relationship with LOS mediated by CSS and ADL. Patients with a high (good) SWB score will tend to have better cognitive skills and perform well in ADL, resulting in a shorter LOS.

\section{Discussion}

This study is the first to examine predictive factors and their relative contributions on inpatient rehabilitation stay for stroke patients in Taiwan using path modeling. The interrelationships between hypothesized predictors and LOS provide thoughts on the magnitude and directions of each predictor on LOS. The simplicity of this model makes it easy to use in the rehabilitation programs by selecting appropriate target functions in order to assist the patients in achieving better outcome.

Three main conclusions emerge from the study. Firstly, age does not have a significant effect on either ADL or CSS (LaPlante, 1991). The finding that the effects of SWB and CSS on LOS were not significant is consistent with the results of an FIM study by Heinemann et al., (1994). Secondly, the total effect of ADL on LOS is the largest one among the three total effects on LOS (SWB on LOS, CSS on LOS and ADL on LOS). The effects of SWB and CSS on LOS are similar in magnitude, and about one-third of the effect of ADL on LOS. Furthermore, ADL is the only significant direct predictor of LOS for stroke patients. The significant effect of ADL on LOS provides evidence that the rehabilitation of patients with strokes needs to be targeted at ADL functions in Asian countries as well (Rondinelli et al., 1991; Heinemann et al., 1994). Thirdly, the effect of SWB on CSS was the largest total effect and direct effect in the model, both being about 1.5 times that of the total effect and direct effect of ADL on LOS, while the indirect effect of SWB on ADL was also the largest in the model. The total effect and direct effect of CSS on ADL were the second largest ones in the model. The impact of SWB and CSS on LOS deserves special attention by medical practitioners. It suggests that an improvement in the patient's SWB may improve CSS and ADL, thereby reducing LOS. Likewise, practitioners may focus on rehabilitation targeted at adapting strategies to enhance patients' cognitive performances relevant to the independence of patients' ADL statuses, so reducing the LOS of patients. 
Table 4 Breakdown of the total effects

\begin{tabular}{|c|c|c|c|c|c|}
\hline Bivariate relationship & Total & Direct effect & Indirect effect & Causal effect & Non-causal effect \\
\hline (Subjective well-being, cognitive-social skills) & 0.5838 & 0.5838 & 0 & 0.5838 & 0 \\
\hline (Subjective well-being, activities of daily living) & 0.4281 & 0.1516 & 0.2765 & 0.4281 & 0 \\
\hline (Subjective well-being, length of stay) & -0.0993 & 0 & -0.1447 & -0.1447 & 0.0454 \\
\hline (Cognitive-social skills, activities of daily living) & 0.5621 & 0.4735 & 0 & 0.4735 & 0.0886 \\
\hline (Cognitive-social skills, length of stay) & -0.1078 & 0 & -0.1600 & -0.1600 & 0.0522 \\
\hline (Activities of daily living, length of stay) & -0.3399 & -0.3880 & 0 & -0.3380 & -0.0481 \\
\hline
\end{tabular}

With the exception of the SWB to ADL path, all paths were statistically significant in the final causal model. The GFI suggests that the final model fits the data well. $\mathrm{ADL}$ is the only direct predictor of LOS. The final path model indicates that SWB, CSS and ADL predict LOS for stroke patients. This path model offers rehabilitation professionals a means of carefully designing treatment plans for stroke patients or for referring them to more appropriate programs.

Since Taiwan is trying to revise its National Health Insurance reimbursement system, the results of the study offer the following possible directions: (1) the results support the trend of establishing a function-related outcome as a basis for the reimbursement system for stroke patients in Taiwan, due to the significant contribution of ADL in the path model; (2) the standardized regression coefficients in the model can be utilized to produce efficient outcomes for stroke patients, providing that each predictor can be accessed in clinical service; and (3) the contribution of SWB in the model stresses that psychosocial aspects for stroke patients are important features in rehabilitation processes and should not be overlooked.

The limitations of this study are as follows. The sample was too small to divide patients into different severity or sub-diagnostic groups, so in-depth results for subgroups are not available. In addition, the model may be improved by adding other factors, such as environmental support or promptness of admission (Harada et al., 1993; Heinemann et al., 1994), client's satisfaction, contribution to the community and motivation for going through therapy.

In conclusion, the current study contributes to clinical practice by providing scientific data for various predictors of rehabilitation stay in stroke patients, and in pointing out the influence of SWB and CSS in the path model.

\section{References}

American Heart Association (2005). Risk factors and coronary heart disease [online]. http://www.americanheart.org/presenter.jhtml?identifier $=500$. [Accessed 17 August 2005].

Beck AT, Steer RA, Brown GK (1996). BDI-/l manual. San Antonio: The Psychological Corporation.

Bowling A (1997). Measuring health: a review of quality of life measurement scales. Buckingham: Open University Press. pp. 36-103.

Chung L, Pan AW, Wang YH (2003). A causal model of rehabilitation resource use for clients with spinal cord injury in Taiwan. J Rehabil Med 35:208-212.
Clark F, Azen SP, Zemke R, Jackson J, Carlson M, Mandel D, et al. (1997). Occupational therapy for independent-living older adults - a randomized controlled trial. JAMA 278:1321-1326.

Counsell C, Dennis M, McDowall M (2004). Predicting functional outcome in acute stroke: comparison of a simple six variable model with other predictive systems and informal clinical prediction. I Neurol Neurosurg Psychiatry 75:401-405.

Crewe NM, Dijkers M (1994). Functional assessment. In: Cushman LA, Scherer MJ (editors): Psychological assessment in medical rehabilitation. Washington: American Psychological Association. pp. 101-140.

Duncan OD (1996). Path analysis: sociological examples. Am J Sociol 72:1-16.

Formations in Health Care. (1992). The LORS American data system (LADS): the national inpatient rehabilitation program evaluation system. Chicago: Formations in Health Care.

Giaquinto S, Buzzelli S, Di Francesco L, Lottarini A, Montenero P, Tonin P, et al. (1999). On the prognosis of outcome after stroke. Acta Neurol Scand 100:202-208.

Harada ND, Sofaer S, Kominski G (1993). Functional status outcomes in rehabilitation: implications for prospective payment. Med Care 31:345-357.

Heinemann AW, Linacre JM, Wright BD, Hamilton BB, Granger C (1994). Predication of rehabilitation outcomes with disability measures. Arch Phys Med Rehabil 75:133-143.

Jeng JS, Lee TK, Chang YC, Huang ZS, Ng SK, Chen RC, et al. (1998). Subtypes and case-fatality rates of stroke: a hospital-based stroke registry in Taiwan (SCAN-IV). J Neurol Sci 156:220-226.

Katz S, Ford AB, Moskowitz RW, Jackson BA, Jaffe MW (1963). Studies of illness in the aged: the index of ADL: a standardized measure of biological and psychosocial function. JAMA 185:914-919.

LaPlante MP (1991). The need for assistance in basic life activities. In: Thompson-Hoffman S, Storck IF (editors): Disability in the United States. New York: Springer. pp. 73-106.

Lin JH, Hsieh CL, Lo SK, Hsiao SF, Huang MH (2003). Prediction of functional outcomes in stroke inpatients receiving rehabilitation. J Formos Med Assoc 102:695-700.

LISREL 8 (1996). User's reference guide, version 8 edition. Chicago: Scientific Software International.

Mahoney FI, Barthel DW (1965). Functional evaluation: the Barthel index. Md State Med J 14:61-65.

McGinnis GE, Osberg JS, DeJong G, Seward ML, Branch LG (1987). Predicting charges for inpatient medical rehabilitation using severity, diagnostic related groups, age, and function. Am J Public Health 77:826-829.

McHugh P, Robinson R (1983). The two-way trade - psychiatry and neuroscience. $\mathrm{Br} J$ Psychiatry 143:303-305.

Ottenbacher KJ, Mann WC, Granger CV, Tomita M, Hurren D, Charvat B (1994). Inter-rater agreement and stability of functional assessment in the communitybased elderly. Arch Phys Med Rehabil 75:1297-1301.

Pan AW (1994). Model of rehabilitation resource use - a new approach [PhD Thesis]. Chicago: University of Illinois at Chicago.

Pan AW, Chung L, Huang Y, Chern J (2000). The development of Taiwanese rehabilitation database system. J Occup Ther Assoc ROC 18:47-58.

Pan AW, Chern JS, Chung L, Lai JS (2001a). Inter-rater and test-retest reliability of the Taiwanese rehabilitation functional scale. Occup Ther Int 8:168-183.

Pan AW, Chung L, Tseng MH (2001b). Development and validation of a rehabilitation functional scale. J Formos Med Assoc 5:389-400.

Pedhazur EJ (1982). Multiple regression and behavioral science. Orlando: Harcourt Brace.

Research Team for WHOQOL-Chinese version (1999). Manual of WHO questionnaire on quality of life-Chinese version. Taiwan: National Taiwan University, Department of Psychology.

Rondinelli RD, Murphy JR, Wilson DH, Miller CC (1991). Predictors of functional outcome and resources utilization in inpatient rehabilitation. Arch Phys Med Rehabil 72:447-453. 
Santus G, Ranzenigo A, Caregnato R (1990). Social and family integration of hemiplegic elderly patients one year after stroke. Stroke 21: 1019-1022.

SAS Institute (1990). SAS user's guide: statistics, version 6.12 edition. Cary: SAS Institute.

Stineman MG, Williams SV (1990). Predicting inpatient rehabilitation length of stay. Arch Phys Med Rehabil 71:881-887.

Streiner DL, Norman GR (1989). Health measurement scales: a practical guide to their development and use. New York: Oxford University Press. pp. 90-92.

Subhash S (1995). Applied multivariate techniques. New York: Springer.

The Stroke Association (2005). The cost of stroke. [online] http://www.stroke. org.uk/professionals/information_and_resources/the_cost_of.html. [Accessed 15 February 2005].
Uniform Data System for Medical Rehabilitation (1995). Guide for the use of the uniform data set for medical rehabilitation (adult FIM), Version 4.0. Buffalo: State University of New York at Buffalo.

Van den Bos GA, Triemstra AH (1999). Quality of life as an instrument for need assessment and outcome assessment of health care in chronic patients. Qual Health Care 8:247-252.

Ware JE (1993). SF-36 Health Survey: manual and interpretation guide. Boston: The Health Institute of New England Medical Center.

Wright S (1960). Path coefficients and path regressions: alternative or complementary concepts? Biometrics 16:189-202.

Yip PK, Jeng JS, Lee TK, Chang YC, Huang ZS, Ng SK, Chen RC (1997). Subtypes of ischemic stroke: a hospital-based stroke registry in Taiwan (SCAN-IV). Stroke 28:2507-2512. 